\title{
Writing Motivation Sources of Teacher Candidates: A Phenomenological Study
}

\author{
Ahmet Demirel \\ Nevsehir Haci Bektas Veli University, Nevsehir, TURKEY \\ Education Faculty
}

Received: 10 June 2021 • Accepted: 26 September 2021 • Published Online: 5 November 2021

\begin{abstract}
Writing motivation is effective on writing behavior and writing habits. The aim of this study is to determine the factors that motivate pre-service teachers to write and thus support their writing habits. For this purpose, the research was designed in accordance with the phenomenological pattern from qualitative research designs. In the research, interviews were conducted with preservice teachers through the semi-structured interview form prepared by the researcher. The data obtained from these interviews were analyzed by content analysis technique. Research findings showed that there were internal (internal) and external (external) factors motivating teacher candidates to write. According the findings, the main internal factors that motivated pre-service teachers to write were positive thoughts and beliefs about writing and writing skills, goals expected to be achieved by writing, and lastly, interest and desire for writing. Requirements and environmental expectations for writing, appreciation and support from family and readers, and the environment which is a positive role model in writing were external factors that motivated pre-service teachers to write. In the study, these factors and student views under these factors were discussed and what could be done to increase their motivation for writing was evaluated.
\end{abstract}

Keywords: writing, writing skill, writing motivation, writing habit, teacher candidates.

\section{Introduction}

Writing is one of the most important discoveries of mankind, which has played a role in the change and development of civilizations from past to present. Schmandt-Besserat and Erard (2008: 8) stated that people form two basic systems consisting of visual symbols for expressing themselves and communicating with others, these are art and writing. Although writing is a powerful tool to influence others, it is also an indispensable part of learning (Graham, Gillespie \& McKeown, 2013: 2-5). Göçer (2014: 8) emphasized that writing is important in the transfer of nations and culture between past and future generations. He also mentioned that the writing is used by humanity to transfer the events of the past to future generations.

Unlike speaking skill, writing skill stands out with its permanence. Writing skill is a skill that can be effective in many different areas of human beings from education life to psychological state. Pajares (2003: 141-142) stated that researchers in the field of writing focused on the processes involved in creating a text, and later on, researchers also began to focus on affective factors for writing. McLeod (1987) noted that affective factors can be effective in all stages of the writing process. McLeod proposed that one of these affective factors that affect the writing

(C) Authors. Terms and conditions of Creative Commons Attribution 4.0 International (CC BY 4.0) apply. Correspondence: Ahmet Demirel, Nevsehir Haci Bektas Veli University, Education Faculty, Nevsehir, TURKEY. E-mail: ahmetdemirel38@hotmail.com. 
process is writing motivation. For this reason, it is necessary to know the factors that affect students' motivation to write, in other words, the factors that motivate them to write. Because acting with this awareness is important in terms of providing motivation for writing and gaining the habit of writing.

\subsection{Literature review}

Motivation includes the forces that influence an individual's decision to engage in and persist through tasks (Wright, Hodges \& McTigue, 2019). Writing motivation emerges as a concept that expresses the interests, desires and motives of the authors for the act of writing. Ülper and Çeliktürk Sezgin (2019) stated that it is not possible to say with certainty that an individual can write a qualified text when he/she has the necessary knowledge and skills to write, that the person should be willing to write text. Bruning and Horn (2000) states that the writers who are motivated to write do not only see writing as a beneficial action, but are willing to participate in the writing processes and their writing anxiety is low. Therefore, in order to achieve a successful writing performance, students should be interested in and willing to write. Otherwise, writing activities can become boring, unnecessary, and stressing, unless there is demand and interest for it.

The relationship between writing motivation and writing success and performance has been mentioned by many researchers (Akyol \& Aktas, 2018; Pajares, 2003; Graham, Berninger \& Fan, 2007; Lam \& Law, 2007; Troia, Harbaugh, Shankland, Wolbers \& Lawrence, 2013). For example, Hidi and Boscolo (2006: 148) stated that there are differences in the perception of writing self-efficacy of students who have differences in their interest in writing; and explained that students with low interest in writing see writing as a boring and painful act, while students who are interested in writing see it as a fun thing. Accordingly, researchers (Akyol, 2013; Tok \& Ünlü, 2014) stated that low motivation and unwillingness to write were problems encountered in the writing process and education. On the other hand, Balta (2018: 234) noted that although writing is a cognitive process, writing competence is related to writing motivation. Therefore, can be predicted that individuals with high writing motivation will be more willing in the writing processes than those with low motivation, and thus, will be more active in these processes.

Writing is a complex problem-solving task in which motivation is important but it is difficult to provide and maintain motivation (Bruning \& Horn, 2000: 34). Lack of motivation and reluctance to write emerges as a problem expressed by many groups, including families, teachers and students. In cases where writing motivation is low, determining the writing goal first will be beneficial to increase motivation. Goals can make a job meaningful, increase the interest and motivation for the job. Indeed, Bruning and Horn (2000: 27-28) stated that encouraging students through authentic writing goals can be effective in increasing writing motivation. In order to increase the motivation for writing, it is also important to choose writing topics suitable for the field of interest. Topic selection in personal interest of the writer may increase the interest and motivation for write (Bruning \& Horn, 2000: 28). For this reason, student preferences should be considered in the selection of topics as much as possible. Sügümlü (2016) found that writing practices implemented by adopting student autonomy can increase writing motivation. Also, Bruning and Horn (2000: 27-28) stated that encouraging students to write about topics that are of personal interest can increase their motivation to write.

It is important to complete the writing process successfully by setting achievable writing goals in providing writing motivation. Goal setting promotes motivation (Bandura, 1986). Bruning and Horn (2000: 27-28) stated that breaking down complex writing tasks and setting very simple writing goals may help to increase writing motivation. However, sharing the writings and providing constructive feedback on the writing are practices that can motivate students to write. Bruning and Horn (2000: 27-28) stated that constructive feedback provided to students can 
increase their motivation to write. Providing a suitable and comfortable writing environment can also be helpful in motivating writing.

Tok, Rachım, and Kuş (2014) found that psychological factors, personal curiosity, family encouragement, reading habits, competitions and teachers' attitudes and behaviors were effective on writing habits of $6^{\text {th }}, 7^{\text {th }}$, and $8^{\text {th }}$ grade students. Ülper and Çeliktürk Sezgin (2019) revealed that students feel the need to write for relaxation, liking, expressing themselves, not forgetting, giving information, communicating and producing. On the other hand, Özdemir (2011) concluded that Turkish teacher candidates generally have writing competence, but do not have the habits of using writing as a literary genre and as a communication tool at the desired level. Similarly, Bağcı and Dilek (2018) stated that teacher candidates' writing habits were not at the expected level.

\subsection{Research question}

Tağa and Ünlü (2013) stated that the lack of regular writing habit negatively affects the development of students' writing skills. However, Demirel and Şahinel (2006) stated that the writing skill can only be improved by writing. All these reveal that students' writing habits should be improved. In order to improve their writing habits, students should be motivated to write. Person not only has different levels of motivation; they also have different motivation sources. That is, not only the level of motivation varies, but also the sources of motivation vary (Ryan \& Deci, 2000). When the literature is reviewed, there is no study that reveals the factors that motivate teacher candidates to write. For this reason, it was aimed to reveal the factors that motivate teachers to write and support their writing habits. As a result, this study aims to answer the following research question: "What are the factors that motivate teacher candidates to write?"

\section{Method}

\subsection{Research design}

In this study, it was aimed to reveal the motivation factors of pre-service teachers for writing. For this purpose, the research was carried out in accordance with the phenomenology pattern, which is one of the qualitative research designs. The phenomenological pattern aims to reveal experiences and meanings by focusing on phenomena that we are aware of but do not have an in-depth and detailed understanding (Yıldırım \& Şimşek, 2018).

\subsection{Participants}

In determining the participants of the study, the habit of writing in free time and the frequency of writing were taken into account. For this reason, 65 pre-service teachers studying at Nevşehir Hacı Bektaş Veli University and Aksaray University were asked about their writing habits and frequency of writing. Among these candidates, 36 candidates with writing habits were selected as the study group. Therefore, in this study, simulated sampling, which aims to define a distinct subgroup by creating a small, similar sample (Yıldırım \& Şimşek, 2018), was used in sample selection. Demographic information of the participants is presented in Table 1. 
A. Demirel - Writing Motivation Sources of Teacher Candidates: A Phenomenological Study

Table 1. Demographic variables related to the participants

\begin{tabular}{clc}
\hline Variables & Woman & $\mathrm{N}$ \\
\hline Gender & Male & 26 \\
& 21 & 10 \\
\hline \multirow{2}{*}{ Age } & 22 & 14 \\
& 23 & 18 \\
& 24 & 2 \\
University & Nevsehir Haci Bektas Veli University & 2 \\
\hline Writing & Aksaray University & 22 \\
Frequency & Often & 14 \\
\hline
\end{tabular}

\subsection{Instruments}

In the present study, two research tools were used. The first is the semi-structured interview form prepared by the researcher to reveal the factors that motivate the participants to write. First of all, the first draft of the semi-structured interview form was prepared. The first draft was sent to two field experts to take their opinions and required corrections were done in accordance with their opinions. The interview form consists of three open-ended that allow to determine questions the factors that motivate the participants to write. The other data collection tool is the personal information form prepared for the purpose of obtaining demographic information of the participants. This form contains questions prepared to determine the demographic variables of the participants.

\subsection{Data collection and analysis}

In the data collection process, semi-structured interviews were conducted because the aim was to systematically learn and understand the factors that influenced the students' writing motivation. Semi-structured interviews allow researchers to get both fixed-option answers and indepth information in an area of interest (Büyüköztürk, Kiliç Çakmak, Akgün, Karadeniz \& Demirel, 2016) and to obtain rich data. The data were analyzed using content analysis technique. Content analysis is used to study the trends and patterns in documents (Stemler, 2001). MAXQDA program was used to analyze the data. During the content analysis, the data were coded by two different coders and in this process, the themes, categories and codes were created. Pre-service teachers were identified by a letter and number coding system in order to conceal their true identities as $\mathrm{P}_{1}, \mathrm{P}_{2}, \mathrm{P}_{3}$ in which P stands for participant. The code book has been prepared in order to ensure compliance in the coding process. At the end of the process, compatibility between coders was calculated for the coding made by two different encoders. The formula suggested by Miles and Huberman (1994) was used to calculate the fit between coders. As a result, it was seen that the agreement between coders (the inter-rater reliability was found to be .92) was .92. Miles, Huberman and Saldana (2014) state that depending on the size and range of the code scheme, the agreement between coders should be between \%85 and \%90. Therefore, it can be said that a sufficient level of agreement between coders was achieved in the study.

\section{Results}

Themes, categories, codes and sub-codes were created as a result of analyzing the obtained data with the content analysis technique. Accordingly, the factors that motivate teacher candidates to write are divided into two categories as intrinsic motivation and extrinsic motivation 
factors. Intrinsic motivation factors and extrinsic motivation factors and the codes under them are as follows:

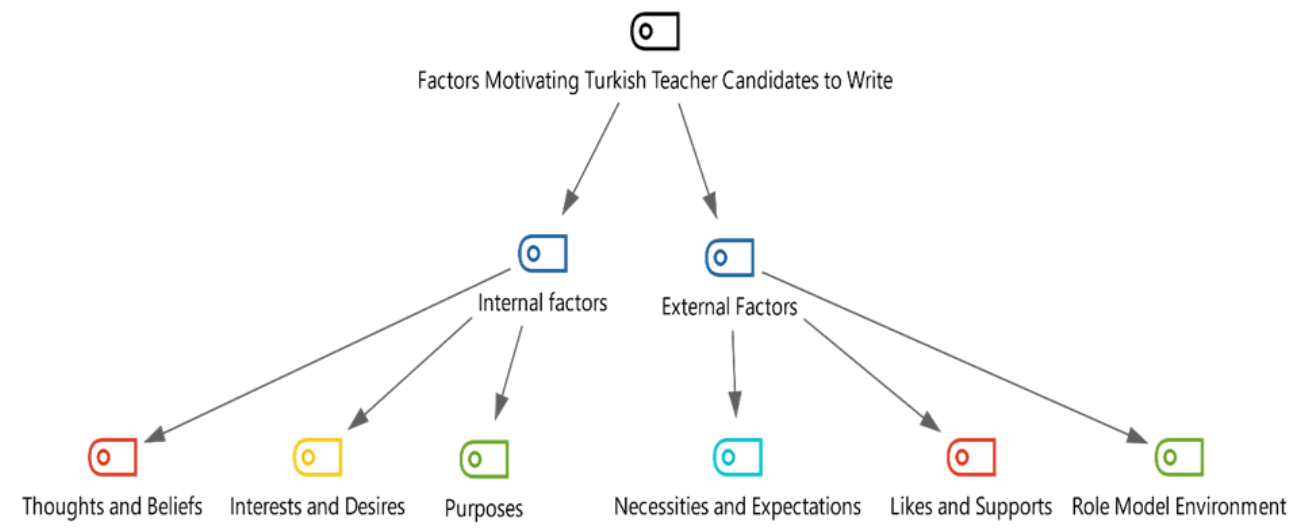

Figure 1.

When the figure above is examined, it is seen that the factors that motivate teacher candidates to write are divided into two categories: internal factors and external factors. The codes under the internal factors category are: "Thoughts and beliefs", "interests and desires" and "goals". In the category of external factors, there are "requirements and expectations", "likes and supports" and finally "role model environment" codes. Below, internal and external factors are considered one by one and the codes related to these factors and the sub-codes under these codes are discussed and interpretations are made by including the direct statements taken from the participants when necessary.

\subsection{Internal factors motivating teacher candidates to write}

The codes and subcodes that are among the internal factors that motivate teacher candidates to write and thus support their writing habits are as follows:

Table 2. Internal factors motivating teacher candidates to write

\begin{tabular}{llc}
\hline Codes & Sub Codes & f \\
\hline & The thought of being able to express more easily by writing & 17 \\
& The belief that writing will lead to personal growth & 17 \\
& The idea that writing improves thinking skills & 17 \\
Thoughts & The belief that writing will improve other language skills & 16 \\
and Beliefs & The idea that writing will improve the imagination & 12 \\
& The belief to express yourself better by writing & 11 \\
& The belief that writing provides insight & 9 \\
& The belief that writing will improve vocabulary & 7 \\
& The thought that writing will improve writing skills & 7 \\
Interests & The thought that writing contributes to knowledge & 6 \\
and & The thought that writing is permanent and effective & 5 \\
Desires & Willingness to be useful by writing & 13 \\
& Desire to be a role model by writing & 9 \\
Purposes & Feels fun to write & 2 \\
\cline { 2 - 3 } & Psychological and emotional relief by writing & 26 \\
& The purpose of socializing by writing & 5 \\
& The purpose of success in education life & 5 \\
\hline
\end{tabular}


In the table above, it is seen that the internal factors motivating teacher candidates to write are grouped under the titles of "thoughts and beliefs", "interests and desires" and "purposes". Accordingly, the thoughts and beliefs that motivate teacher candidates to write are given below.

\subsection{Thoughts and beliefs that motivate writing}

One of the factors that motivate teacher candidates to write is thoughts and beliefs. Some of these thoughts and beliefs are presented below.

"I think writing is one of the most comfortable ways to be understood. Being able to write is, in my opinion, proof of freedom of thought. You write down what they cannot speak or shout. You empty all your insides and regain strength. As you write, you rethink what you have written and maybe see that you want to draw a new route for yourself, and you go that way. Human exceeds the limits of writing in my opinion" (P26).

"When I write, I think I express what I want to tell better and the people who read it understand me better. That's why I'm writing" $\left(\mathrm{P}_{3}\right)$.

"I can express my thoughts in a more beautiful and comfortable way. I can hardly do this verbally. But I can express it well in writing" (P28).

"I think writing improves people personally. It gives different perspectives. It enables critical thinking. It provides to be prepared and planned" (P6).

"Just as teachers and academicians improve themselves when they write an article, I can improve myself by writing. That's why I write often" ( $\left.\mathrm{P}_{7}\right)$.

"It is nice to express one's feelings and thoughts in writing, because the person who writes is also the person who reads and improves himself. It sheds light on both itself and its surroundings" (P29).

"Writing improves the writing skill of the person as well as positively affects reading and thinking skills" (P29).

Beliefs and thoughts that are among the internal factors motivating teacher candidates to write are listed above. The thoughts and beliefs that motivate participants to write are as follows: The thought of expressing themselves more comfortably by writing, the thought that writing contributes to knowledge, the thought that writing gives insight, the idea that writing will improve their thinking skills, the idea that writing will improve their imagination, and the thought of expressing themselves better by writing. Apart from thoughts and beliefs, one of the internal factors that motivate the participants to write is interest and desire. The interests and wishes that motivate prospective teachers to write are discussed below.

\subsection{The interests and desires that motivate to write}

One of the factors that motivates pre-service language teachers to write is their interests and desires. Some of these interests and desires are presented below:

"It is a very big event for me to be affected other people by what I write. There are lives that change with a single sentence and I would like to be a writer who creates those life-changing sentences" ( $\mathrm{P} 13)$.

"Writing allows people around us to be influenced by us and create the same feelings and be willing to write" (P6).

"For example, if I write poetry, if I have my brother read it, he will see it and write poetry and he may be affected. I write a poem and set an example for them" (P1). 
"Writing enables people around us to be influenced by us, and they also have the same feelings and are willing to write" (P6).

"Writing and imagination keeps life from being monotonous and boring. It is a platform that has everything you want. You decide everything in that world. That's why this duo makes me" (P15).

"Writing is something that I believe is very helpful to myself. When I write what I could not tell anyone, there is a I happier" (P21).

"Because sometimes a person wants to talk to someone, needs this and there is no one to talk to. At such times, it will be good for every person to sit down and write. Most of us do this anyway" (P9).

The aims, which are among the internal factors that motivate pre-service teachers to write, are listed above. According to the findings, it is seen that psychological and emotional relaxation, socialization, being successful in education life and being successful in professional life are goals that motivate participants to write. Apart from the intrinsic (intrinsic) motivation factors that motivate prospective teachers to write, there are also external motivation factors. These external factors motivating the participants to write are discussed below.

\subsection{External factors motivating teacher candidates to write}

The codes and sub-codes that are among the external factors that motivate teacher candidates to write and support their writing habits are as follows:

Table 3. External factors motivating teacher candidates to write

\begin{tabular}{clc}
\hline Codes & Sub Codes & $\mathrm{f}$ \\
\hline \multirow{3}{*}{$\begin{array}{c}\text { Necessities and } \\
\text { Expectations }\end{array}$} & Teacher expectations & 6 \\
& Environmental expectations & 3 \\
Likes and Supports & Communication requirement & 4 \\
\cline { 2 - 3 } & Assignments, reports, presentations, etc. tasks & 7 \\
\cline { 2 - 3 } Role Model & Readers' likes and support & 3 \\
& Likes and support of the immediate & 4 \\
& environment & 5 \\
\hline
\end{tabular}

In the table above, it is seen that the external (external) factors that motivate teacher candidates to write are grouped under the titles of "necessities and expectations", "likes and supports" and "role model environment". These topics are discussed one by one below:

\subsection{Necessities and expectations}

Some of the participants stated that they have requirements and expectations for writing. This is one of the factors that motivates them to write. These requirements and expectations are teacher expectations, environmental expectations, communication necessity and homework, reports, presentations, etc. are collected under the headings of preparation requirement. Some of the statements of the preservice teachers regarding these are as follows: 
"I think that when I write, I express what I want to tell better and the people who read it understand me better. That's why I have to write" ( $\left.\mathrm{P}_{3}\right)$.

"A person improves himself in expressing his feelings and thoughts by writing. Writing helps me express my feelings and thoughts more accurately. That's why it is necessary to write" ( $\left.\mathrm{P}_{5}\right)$.

As can be understood from the statements above, the participants stated that it is necessary to write and that there are expectations from them in this regard. These expectations and requirements expressed by the participants are among the external factors that motivate them to write. Apart from these, another factor that motivates teacher candidates to write is the liking and support. Based on the expressions of the participants, the likes and supports that are understood to motivate them to write are given below.

\subsection{Likes and supports}

Participants state that readers' appreciation and support is one of the factors that motivate them to write. These likes and supports are grouped under the subtitles of appreciation and support of the reader and close circle. Some of his expressions about likes and supports that motivate the participants to write are as follows:

"We share what we have written with those around us. Even a positive feedback from them can motivate us to write" (P17).

"When an article is written about a topic, there is a transfer of information. Readers, on the other hand, can benefit from reading this or make their criticism to the person who wrote it. Thus, both the reader and the writer can improve themselves" ( $\left.\mathrm{P}_{30}\right)$.

"My brother had read it and liked it very much and then he started to read such articles. This motivated me" (P6).

Based on the statements above, it can be said that the likes and supports expressed especially by the reader and the close environment are among the external factors that motivate the participants to write. Apart from likes and supports, one of the external sources that motivates participants to write is the role model environment. Based on the expressions of the participants, role models, which are one of the external sources that motivate them to write, are given below.

\subsection{Role model environment}

Participants stated that role model family members and friends are one of the external factors that motivate them to write. According to the participants, the role model friendship and family members are factors that motivate them to write. Some of the expressions of the participants about the role models that motivated them to write are as follows:

"My friend was telling that I am writing constantly, and then I was impressed. This habit has gradually developed, and my friends set an example for me" (P1).

"When I have emotional intensity, I write my feelings on paper. I got this habit from my friend. I read the article he wrote. I was impressed and I wrote too" $\left(\mathrm{P}_{5}\right)$.

Based on the statements above, it is understood that one of the external factors motivating the participants to write is role models. It is seen that especially role model friends and family members are one of the factors that motivate writing. 


\section{Discussion}

The aim of the present study was to determine the factors that motivate pre-service teachers to write and support their writing habits. The study showed that the factors motivating pre-service teachers to write can be divided into two as intrinsic and extrinsic factors. This findings is in line with the previous findings. For example, McLeod (1987: 429) emphasized intrinsic and extrinsic motivation factors in writing motivation and stated that these factors affect the writing process. Similarly, Bruning and Horn (2000) also emphasized intrinsic and extrinsic factors in this writing motivation and talked about their development.

This study showed that prospective teachers' positive thoughts and beliefs about writing, as well as their interests and desires, as well as their writing goals, appeared to be internal factors that motivated them to write in general. This findings is in line with the previous findings. For example, Bruning and Horn (2000) found that in order to improve the intrinsic motivation of writing, it is necessary to form student beliefs about the nature and potential of writing. In addition, Troia, Shankland and Wolbers (2012) emphasized the importance of personal and situational interests on writing motivation.

This study showed that the necessity of writing and their expectations for writing, the admiration and support obtained from writing, and the role model environment that sets an example for them to write are the main external factors that motivate pre-service teachers to write. This findings is in line with the previous findings. For example, Tok, Rachım, and Kuş (2014), in their study on students who have acquired the habit of writing, concluded that the verbal feedback given by the teachers were effective in gaining a writing habit and motivation. The findings of Baker, Scher, and Mackler (1997) showed that family and environment have an effect on reading motivation. This finding supports the importance of the role models in terms of motivation.

According to the findings of the research, positive thoughts and beliefs about writing are the leading factors that motivate prospective teachers to write. Thinking that you can express yourself more comfortably by writing, thinking that writing will provide personal development, the idea of developing thinking skills by writing, the belief that writing will improve other language skills, the thought that writing will improve their imagination and expression are the main thoughts and beliefs that motivate teacher candidates to write. Bruning and Horn (2000: 34) stated that in order to develop intrinsic motivation for writing, student beliefs should be formed about the nature and potential of writing. These findings reveal that developing positive feelings and thoughts for writing is important for increasing writing motivation.

Research findings show that another motivation source is interest and desire for writing. Hidi and Boscolo (2006: 148) stated that the interest in writing is related to motivation and stated that students who are interested in writing see writing as an entertaining job. Being a role model for other people by writing, being useful for them and shows interests and desires for writing. This finding reveals the importance of gaining writing interest and desire in terms of providing motivation for writing and gaining writing fluidity. Latif (2020) emphasized the relationship between writing interest and writing motivation, and even mentioned that these concepts can be used interchangeably. Writing interest and desire can be developed with fun writing activities and suggestions.

According to the findings, another intrinsic motivation source that motivates participants to write is goals. The goals of relaxation, socialization, and achievement through writing are the main internal factors that motivate pre-service teachers to write. Bruning and Horn (2000: 34) also stated the importance of original writing goals in terms of writing motivation. However, Ülper and Çeliktürk Sezgin (2019) stated in their study that one of the writing purposes of students in the faculty of education is relaxation. Tok, Rachım, and Kuş (2014) stated in their study on writing habits that psychological factors are effective on writing habits. In addition, 
Singer and Singer (2010) emphasized that writing is a skill that can be used for physical and emotional healing and its effectiveness is also revealed in clinical research.

In this study, it was seen that requirements and environmental expectations were the leading sources of external motivation for writing. Having responsibilities such as writing homework is one of the factors that motivate prospective teachers to write. Having responsibilities is one of the requirements and expectations that motivate pre-service teachers to write. These findings reveal the importance of giving students various responsibilities in order to gain motivation and habit of writing. Tok, Rachım and Kuş (2014) stated that family encouragement is effective on writing habits. Ülper and Çeliktürk Sezgin (2019) also stated that families, teachers and friends are among the people who direct education faculty students to write.

According to the findings of the present study, another motivation source that motivates teacher candidates to write is the appreciation and support expressed by the reader and the environment. The positive feedback made by the readers towards the writing process and the expressions of the likes and support of the writings and the writing process by the family and close friends motivate the teacher candidates to write and thus support their writing habits. Likes and supports may increase their motivation by affecting their author self-efficacy perceptions. As a matter of fact, author self-efficacy is related to motivation (Pajares, Valiante \& Cheong, 2007).

According to the findings, another source of motivation is positive role models in terms of writing habits. In particular, the role model family members and the role model friends appear as factors that support the motivation and habit of writing. Graham (2006) emphasized that a teacher with writing skills and habits would be a good role model for his students. For this reason, that teachers and families have an exemplary attitude towards writing is important in terms of writing motivation and habits.

\section{Conclusions}

The results indicated that it is important for families and teachers to be role models in writing in terms of providing students' writing motivation. For this reason, teachers and families should be role models for students in writing in order to gain motivation and habit of writing. For this purpose, parents and teachers can set an example for them with activities that support regular writing habits such as keeping diaries and travel notes. Thoughts and beliefs about writing and its effects also affect writing motivation. Teachers and families should collaborate so that students develop positive thoughts and beliefs about writing in order to increase their motivation to write. For this reason, it is extremely important to make students aware of the importance of writing skills and the positive effects that writing can have on the environment and the individual. This will affect the value they give to writing. Akyol and Aktaş (2018) stated that one of the concepts related to writing motivation is task value. Task value is related to how much a student values him. In the addition another factor related that writing motivation, like and supports. As a matter of fact, feedbacks are instructional practices that can increase both skills and motivation (Duijnhouwer, Prins \& Stokking, 2012). Therefore, encouraging students by parents and teachers and giving them constructive feedback is important in terms of gaining motivation for writing and supporting their writing habits. Setting a goal for writing also affects writing motivation. For this reason, teachers should guide their students in determining writing worth and achievable writing goals.

Research findings showed that teacher candidates have many different sources of motivation for writing. Nolen (2007: 221) states that reading and writing fields are rich areas for research on motivations because there are many reasons for reading and writing activities. This research provides guiding findings in increasing students' writing motivation and supporting their writing habits. In future studies, based on the motivational factors set forth in this study, what 
practices can be used to support writing habits and the effectiveness of these practices will contribute to the support of students' writing interests and habits.

\section{Acknowledgements}

This research did not receive any specific grant from funding agencies in the public commercial, or not-for-profit sectors.

The author declares no competing interests.

\section{References}

Akyol, H., \& Aktas, N. (2018). The relationship between fourth-grade primary school students' story-writing skills and their motivation to write. Universal Journal of Educational Research, 6(12), 27722779. https://www.doi.org/10.13189/ujer.2018.061211

Bağcı, H., \& Dilek, B. A. Z. (2018). Türkçe öğretmen adaylarinin yazma alişkanliklari üzerine bir çalişma [A study on the writing habits of Turkish teacher candidates]. Ana Dili Eğitimi Dergisi, 6(4), 1138-1160.

Baker, L., Scher, D., \& Mackler, K. (1997). Home and family influences on motivations for reading. Educational psychologist, 32(2), 69-82. https://www.doi.org/10.1207/s15326985ep3202_2

Balta, E. E. (2018). The relationships among writing skills, writing anxiety and metacognitive awareness. Journal of Education and Learning, 7(3), 233-241. https://www.doi.org/10.5539/jel.v7n3p233

Bandura A. (1986). Social foundations of thought and action: A social cognitive theory. Englewood Cliffs (NJ): Prentice-Hall.

Bruning, R., \& Horn, C. (2000). Developing motivation to write. Educational psychologist, 35(1), 25-37. https://www.doi.org/10.1207/S15326985EP3501 4

Büyüköztürk, Ş., Kiliç Çakmak, E., Akgün, O.E., Karadeniz, Ş., \& Demirel, F. (2016). Bilimsel araştırma yöntemleri [Scientific research methods]. Ankara: Pegem Akademi.

Demirel, Ö. ve Şahinel, M. (2006). Türkçe ve sinif öğretmenleri için Türkçe öğretimi [Teaching Turkish for Turkish and classroom teachers]. Ankara: Pegem Akademi.

Duijnhouwer, H., Prins, F. J., \& Stokking, K. M. (2012). Feedback providing improvement strategies and reflection on feedback use: Effects on students' writing motivation, process, and performance. Learning and Instruction, 22(3), 171-184. https://www.doi.org/10.1016/j.learninstruc.2011.10.003

Göçer, A. (2014). Yazma eğitimi [Writing training]. Ankara: Pegem Akademi.

Graham, S. (2006). Strategy instruction and the teaching of writing. In C. MacArthur, S. Graham \& J. Fitzgerald (Eds.), Handbook of writing research (pp. 187-207). New York: The Guilford Press.

Graham, S., Berninger, V., \& Fan, W. (2007). The structural relationship between writing attitude and writing achievement in first and third grade students. Contemporary educational psychology, 32(3), 516-536. https://www.doi.org/10.1016/j.cedpsych.2007.01.002

Graham, S., Gillespie, A., \& McKeown, D. (2013). Writing: Importance, development, and instruction. Reading and Writing, 26(1), 1-15. https://www.doi.org/10.1007/s11145-0129395-2 
Hidi, S., \& Boscolo, P. (2006). Motivation and writing. In C. A. MacArthur, S. Graham \& J. Fitzgerald (Eds.), Handbook of writing research (pp. 144-157). New York, NY: Guilford Press.

Lam, S. F., \& Law, Y. K. (2007). The roles of instructional practices and motivation in writing performance. The Journal of Experimental Education, 75(2), 145-164. https://www.doi.org/10.3200/JEXE.75.2.145-164

Latif, M. M. A. (2020). Writing motivation research, measurement and pedagogy. New York, NY: Routledge.

McLeod, S. (1987). Some thoughts about feelings: The affective domain and the writing process. College Composition and Communication, 38(4), 426-435. https://www.doi.org/10.2307/357635

Miles, M. B., \& Huberman, A. M. (1994). Qualitative data analysis: An expanded sourcebook (2 ${ }^{\text {nd }}$ ed.). Thousand Oaks, CA: Sage.

Miles, M. B., Huberman, A. M., \& Saldana, J. (2014). Qualitative data analysis: A methods sourcebook (3 ${ }^{\text {rd }}$ ed.). Los Angeles: Sage.

Nolen, S. B. (2007). Young children's motivation to read and write: Development in social contexts. Cognition and instruction, 25(2-3), 219-270.

https://www.doi.org/10.1080/07370000701301174

Özdemir, N. H. (2011). Türkçe öğretmeni adaylarının yazma alışkanlıkları üzerine bir araştırma (Unpublished master's thesis) [A research on the writing habits of Turkish teacher candidates]. İnönü Üniversitesi Eğitim Bilimleri Enstitüsü, Malatya.

Pajares, F. (2003). Self-efficacy beliefs, motivation, and achievement in writing: A review of the literature. Reading \& Writing Quarterly, 19(2), 139-158. https://www.doi.org/10.1080/10573560308222

Pajares, F., Valiante, G., \& Cheong, Y. F. (2007). Writing self-efficacy and its relation to gender, writing motivation and writing competence: A developmental perspective. In S. Hidi \& P. Boscolo (Eds.), Writing and motivation (pp. 141-159). Oxford, England: Elsevier.

Ryan, R. M., \& Deci, E. L. (2000). Intrinsic and extrinsic motivations: Classic definitions and new directions. Contemporary educational psychology, 25(1), 54-67. https://www.doi.org/10.1006/ceps.1999.1020

Schmandt-Besserat, D., \& Erard, M. (2008). Origins and forms of writing. In C. Bazerman (Ed.), Handbook of research on writing: History, society, school, individual, text. New York, NY: Routledge.

Singer, J., \& Singer, H. S. (2010). Writing as physical and emotional healing: Findings from clinical research. In C. Bazerman (Ed.), Handbook of research on writing: History, society, school, individual, text (pp. 485-498). New York, NY: Routledge.

Stemler S. (2001). An overview of content analysis. Practical assessment. Research \& Evaluation, 7(17), 137146.

Süğ̈̈mlü, Ü. (2016). Yazma becerisinde öğrenci özerkliğinin yazmaya yönelik tutum ve motivasyonla ilişkisi: Bir eylem araştırması (Unpublished doctoral dissertation) [The relationship of student autonomy in writing skill with attitude and motivation towards writing: An action research]. Sakarya Üniversitesi Eğitim Bilimleri Enstitüsü, Sakarya.

Tağa, T., \& Ünlü, S. (2013). Yazma eğitiminde karşılaşılan sorunlar üzerine bir inceleme [A review on the problems encountered in writing education]. Electronic Turkish Studies, 8(8), 1285-1299.

Tok, M. \& Ünlü, S. (2014). Yazma becerisi sorunlarının ilkokul, ortaokul ve lise öğretmenlerinin görüşleri doğrultusunda karşılaştırılmalı olarak değerlendirilmesi [Comparative evaluation of writing skills problems in line with the opinions of primary, secondary and high school teachers]. Elektronik Sosyal Bilimler Dergisi, 13(50), 73-95. https://www.doi.org/10.17755/esosder.04506

Tok, M., Rachım, S., \& Kuş, A. (2014). Yazma alışkanlığı kazanmış öğrencilerin yazma nedenlerinin incelenmesi [Examining the writing reasons of students who have acquired the habit of 
writing]. Gazi Üniversitesi Gazi Eğitim Fakültesi Dergisi, 34(2), 267-292. https://www.doi.org/10.17152/gefd.36525

Troia, G. A., Harbaugh, A. G., Shankland, R. K., Wolbers, K. A., \& Lawrence, A. M. (2013). Relationships between writing motivation, writing activity, and writing performance: Effects of grade, sex, and ability. Reading and Writing, 26(1), 17-44. https://www.doi.org/10.1007/s11145-0129379-2

Troia, G. A., Shankland, R. K., \& Wolbers, K. A. (2012). Motivation research in writing: Theoretical and empirical considerations. Reading \& Writing Quarterly, 28(1), 5-28. https://www.doi.org/10.1080/10573569.2012.632729

Ülper, H., \& Çeliktürk Sezgin, Z. (2019). Eğitim fakültesi öğrencilerinin yazma alışkanlığı Profillerinin Belirlenmesi [Determining the writing habit profiles of Education Faculty students]. Mehmet Akif Ersoy Üniversitesi Ë̆itim Fakültesi Dergisi, (49), 166-170. https://www.doi.org/10.21764/maeuefd.428605

Wright, K. L., Hodges, T. S., \& McTigue, E. M. (2019). A validation program for the Self-Beliefs, WritingBeliefs, and Attitude Survey: A measure of adolescents' motivation toward writing. Assessing Writing, (39), 64-78. https://www.doi.org/10.1016/j.asw.2018.12.004

Yıldırım, A., \& Şimşek, H. (2018). Sosyal bilimlerde nitel araştırma yöntemlerİ (11. Baskı) [Qualitative research methods in the social sciences]. Ankara: Seçkin Yayıncılık. 
A. Demirel - Writing Motivation Sources of Teacher Candidates: A Phenomenological Study

C $O$ A $\mathbf{s}$ 